American Journal of Applied Sciences 8 (12): 1307-1313, 2011

ISSN 1546-9239

(C) 2011 Science Publications

\title{
Vertical Profile of C, N, P, K and Radionuclides in Soil Collected from Highland Tea Plantation Areas
}

\author{
${ }^{1}$ Zaini Hamzah, ${ }^{1}$ Seh Datul Riduan and ${ }^{2}$ Ahmad Saat \\ ${ }^{1}$ Faculty of Applied Sciences, \\ ${ }^{2}$ Institute of Science, Universiti Teknologi MARA, \\ University Teknology MARA, 40450 Shah Alam, Selangor, Malaysia
}

\begin{abstract}
Problem statement: Cameron Highlands is a well known agricultural area in Peninsular Malaysia. Long term usage of fertilizer has caused accumulation of major elemental component in the soil. This accumulation will cause enrichment of the nutrient in the catchment located at downstream of the river through runoff. Approach: Two tea plantations on the upstream with hilly condition plantation were selected as the location for monitoring the accumulation of the major nutrient component N, P and K. C was also determined to estimate the total organic content in the soil. Natural radionuclides i.e., ${ }^{226} \mathrm{Ra},{ }^{228} \mathrm{Ra}$ and ${ }^{40} \mathrm{~K}$ were also determined and anthropogenic radionuclides ${ }^{137} \mathrm{Cs}$ were detectable. The samples were measured using Elemental Analyzer, Energy Dispersive X-rays Fluorescence (EDXRF) and gamma spectrometer. The data set were analyzed using Principle Component Analysis (PCA) and Cluster Analysis (CA) to check the distribution and elemental sources. Results: The trend for all depth profile measurement results shown monotonically trend through the depth where it shown no observable trend except for $\mathrm{C}, \mathrm{N}, \mathrm{P}$ and ${ }^{137} \mathrm{Cs}$ decreasing through the depth. PCA results indicate that there are two sources for plantation A and three sources for plantation B that led to the accumulation of these elements. Three clusters of group element were found for both tea plantation area and the major sources are from fertilizer, natural occurring and atmospheric natural process. The model for $\mathrm{C}, \mathrm{N}$ and $\mathrm{P}$ was found to be exponentially proportional to the depth with removing mixing layer. Conclusion: The range of concentrations for measured elements shows that the concentrations of elements in tea plantation B are higher than in tea plantation A. All depth profile gives monotonically trend except for $\mathrm{C}, \mathrm{N}, \mathrm{P}$ and ${ }^{137} \mathrm{Cs}$ since these elements were added to the soil. $\mathrm{C}, \mathrm{N}$ and $\mathrm{P}$ are decreasing exponentially with depth. The amount of ${ }^{137} \mathrm{Cs}$ was found to be detectable for both study locations and it was from the fall out of nuclear explosion. Other radionuclides seem to be from natural existence and atmospheric natural process.
\end{abstract}

Key words: Soil erosion, soil profile, elemental analyzer, EDXRF, gamma spectrometry, vertical trend, cameron highlands, tea plantation, exponentially proportional, cultivated area

\section{INTRODUCTION}

Tea plantation in Cameron Highlands is a long life time plantation on high hill slopes that extended to more than 50 years. Long term usage of fertilizer had enriched the cultivated area with major component of fertilizer such as N, P and $\mathrm{K}$ in soil. The accumulated fertilizer that is not absorbed by the roots will be easily removed by runoff on the slope surface as well as leaching into the soil. Overused fertilizer will cause nonpoint pollution (Novotny et al., 2010; Guo et al., 2011; Carpenter et al., 1998; Choudhury and Kennedy, 2005). Besides the normal major components chemical fertilizers of potash based and other type of fertilizer also contained appreciable amount of radionuclides (Alam et al., 1997; Chandrajith et al., 2010; Favaro, 2005). The high hill of Cameron Highlands, Malaysia sit on the intermediate igneous rock mountain range (Ministry of Agriculture and Fisheries, 1970). Being igneous in origin the soil is known to contain natural radionuclides of uranium and thorium origins and ${ }^{40} \mathrm{~K}$ (Ademola et al., 2010; Anjos et al., 2005; El-Arabi 2007; Moura et al., 2011). With high altitude of more than $1100 \mathrm{~m}$ from sea level, it is suspected that the anthropogenic radionuclide ${ }^{137} \mathrm{Cs}$ also deposited in the soil (Lettner et al., 2006; McGee et al., 1992). With the hilly location up to $20^{\circ}$ gradient steep slope, the runoff is much greater than flat area (Aminuddin et al., 2005).

Corresponding Author: Zaini Hamzah, Faculty of Applied Sciences, Universiti Teknologi MARA, 40450 Shah Alam, Selangor, Malaysia 
Previous research at Cameron Highlands shows large amount of sediment accumulation at Sultan Abu Bakar Dam due to soil erosion (Hamzah et al., 2011; Riduan et al., 2009). The usage of fertilizer in Malaysia for industrial group including tea plantation has increased each year although without increased in the plantation's area (FAOUN, 2004). Tea plantations occupy $40 \%$ fraction of total agriculture area at Cameron Highlands (Aminuddin et al., 2005). Without controlling the usage of fertilizer at tea plantation, the unused fertilizers will increases and also sweep by runoff.

\section{MATERIALS AND METHODS}

Sampling: Soil samples were collected at two tea plantations area in Cameron Highlands, Malaysia. The two locations are known as plantation A and plantation B. Seven sampling points were set at plantation A and six sampling point at plantation $\mathrm{B}$ and each sampling point location was determined using Global Positioning System (GPS). At each sampling point, ten profile soil samples up to $20 \mathrm{~cm}$ were taken as representative sample using hand auger. Each profile samples were sub-sampled at $2 \mathrm{~cm}$ slice. Two times drilling were necessary to get a profile up to $20 \mathrm{~cm}$ depth. Subsampled of the same layer was mix together. They were oven dried at $60^{\circ} \mathrm{C}$ until the constant weight achieved. The samples were then ground, homogenized and sieved using $250 \mu \mathrm{m}$ sieve (Hamzah et al., 2008). Each of the samples was stored in a plastic container, sealed and labeled.

Elemental Analyzer Measurement: C and N were determining using LECO CHNS-932 elemental analyzer. Each sample was weighted at $2.0 \mathrm{mg}$ using micro balance into tin capsules. Five replicate for each sample was measured to maintain the consistent result. Standard sulphamethazine was used to calibrate the instrument. Blank sample was inserted between five replicates to flush the remaining contaminant before starting new sample measurement.

Energy Dispersive X-Ray Fluorescence (EDXRF) measurement: Pellet with $32 \mathrm{~mm}$ diameter and $2 \mathrm{~mm}$ thickness was prepared by pressing about $2 \mathrm{~g}$ of sample using fusion machine at 15 tonne presure. Duplicate samples were prepared and measured using Minipal4 PANalytical bench-top EDXRF and the tube ratings were set to $300 \mathrm{mV}, 150 \mu \mathrm{A}$ with $\mathrm{Rh}$ target. Al-thin filter was used for measuring $\mathrm{K}$, Mo filter for $\mathrm{U}$ and $\mathrm{Th}$ and no filter for $\mathrm{P} . \mathrm{K}_{\alpha}$ line was used in quantitative of $\mathrm{P}$ and $\mathrm{K}$ at energy $2.013 \mathrm{keV}$ and $3.312 \mathrm{keV}, \mathrm{L}_{\alpha}$ line was used to measured $\mathrm{U}(13.612 \mathrm{keV})$ and $\mathrm{Th}(12.967 \mathrm{keV})$ with 100 second measuring time as optimize in our laboratory (Abdullah et al., 2011). Standard calibration for $\mathrm{P}$ and $\mathrm{K}$ was carried out by using series of dilution of $\mathrm{K}_{2} \mathrm{HPO}_{4}$, Standard Reference Material IAEA 312, IAEA 313, IAEA SL-1, IAEA Soil 7 and IAEA SL-1 for U and IAEA RG-Th-1 for Th (Hamzah et al., 2011). Standard addition method was applied to soil samples to eliminate the matrix effect for $\mathrm{P}$ and $\mathrm{K}$. The measurement conditions for standard and samples were set to be identical.

Gamma Spectrometer Measurement: About $400 \mathrm{~g}$ of samples was placed in plastic container, sealed and leaved for at least 3 weeks for the radionuclides in the samples to reach secular equilibrium state between parent and progenies (Alias et al., 2008). Each sample was counted using HPGe detector for $12 \mathrm{~h}$. The spectrums were analyzed using GammaVision sofware to determine the activity concentration of ${ }^{226} \mathrm{Ra},{ }^{228} \mathrm{Ra}$, ${ }^{40} \mathrm{~K}$ and ${ }^{137} \mathrm{Cs}$.

Statistical analysis: To confirm the relationship between these elements, Pearson correlation were applied. Principal Component Analysis (PCA) and Cluster Analysis (CA) were used to identify whether the element came from same group perform using statistical analysis software XLSTAT.

\section{RESULTS}

Figure 1-10 show the average profile concentration of $\mathrm{C}, \mathrm{N}, \mathrm{P}, \mathrm{K}$ and radionuclides in soil for plantaions A and B. The Depth profile showed monotonic trend through the depth except for C, N, P and ${ }^{137} \mathrm{Cs}$ where it trend is decreasing through the depth. The concentration ranges of $\mathrm{C}, \mathrm{N}, \mathrm{P}, \mathrm{K}, \mathrm{U}, \mathrm{Th}$, ${ }^{226} \mathrm{Ra},{ }^{228} \mathrm{Ra},{ }^{40} \mathrm{~K}$ and ${ }^{137} \mathrm{Cs}$ for plantations $\mathrm{A}$ and $\mathrm{B}$ are tabulated in Table 1.

Table 1: Range of concentrations and range of activity concentrations for elements and radionuclides

\begin{tabular}{llrc}
\hline Element & Unit & Plantation A & Plantation B \\
\hline $\mathrm{C}$ & $\mathrm{mg} / \mathrm{kg}$ & $669-30767$ & $26950-85058$ \\
$\mathrm{~N}$ & $\mathrm{mg} / \mathrm{kg}$ & $288.3-2338.3$ & $1755.0-6162.5$ \\
$\mathrm{P}$ & $\mathrm{mg} / \mathrm{kg}$ & $936.6-2068.4$ & $1251.8-4848.6$ \\
$\mathrm{~K}$ & $\mathrm{mg} / \mathrm{kg}$ & $3859.3-4454.2$ & $7275.4-7761.1$ \\
$\mathrm{U}$ & $\mathrm{mg} / \mathrm{kg}$ & $5.40-6.50$ & $12.1-13.00$ \\
$\mathrm{Th}$ & $\mathrm{mg} / \mathrm{kg}$ & $27.3-30.50$ & $56.9-71.10$ \\
${ }^{226} \mathrm{Ra}$ & $\mathrm{Bq} / \mathrm{kg}$ & $50.2-69.6$ & $98.6-119.9$ \\
${ }^{228} \mathrm{Ra}$ & $\mathrm{Bq} / \mathrm{kg}$ & $97.4-124.0$ & $186.2-253.2$ \\
${ }^{40} \mathrm{~K}$ & $\mathrm{~Bq} / \mathrm{kg}$ & $190.1-221.8$ & $305.6-378.8$ \\
${ }^{137} \mathrm{Cs}$ & $\mathrm{Bq} / \mathrm{kg}$ & $0.68-1.47$ & $0.86-1.99$ \\
\hline
\end{tabular}


Am. J. Applied Sci., 8 (12): 1307-1313, 2011

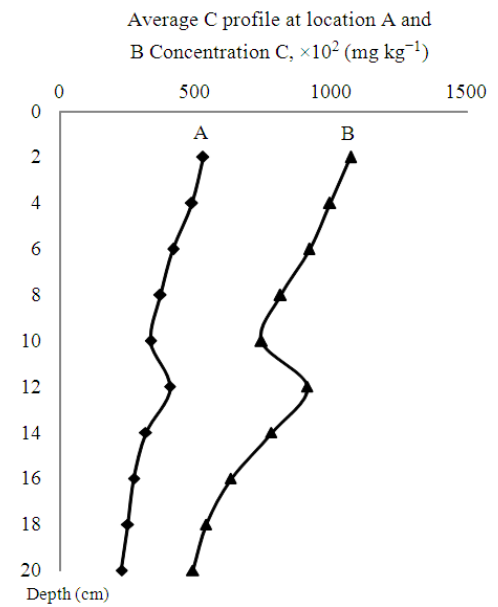

Fig. 1: Carbon profile

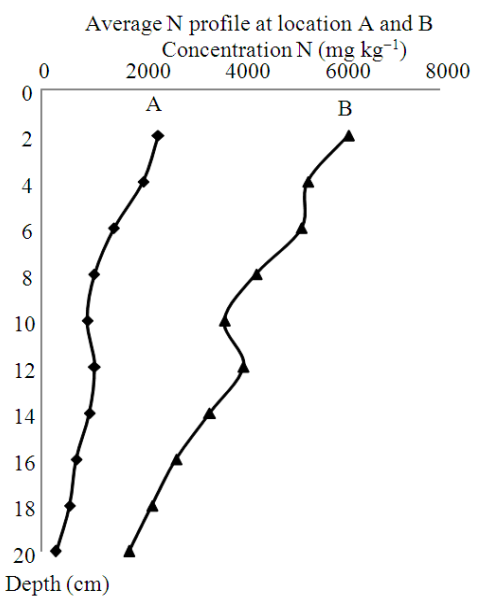

Fig. 2: Nitrogen profile

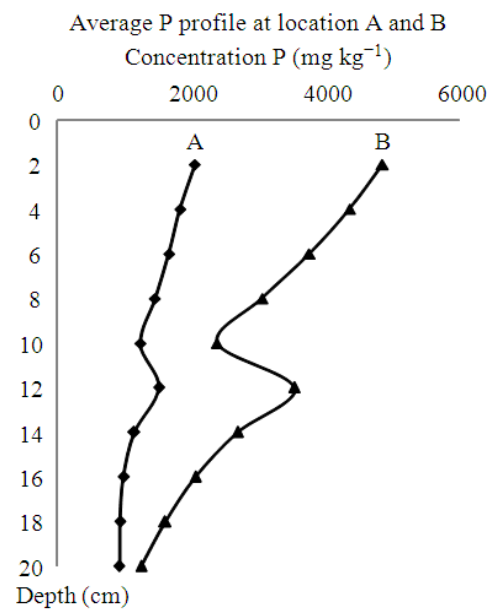

Fig. 3: Phosphorous profile

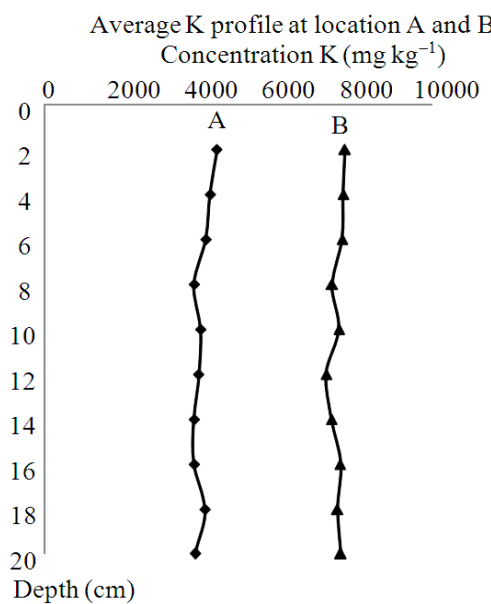

Fig. 4: Potassium profile

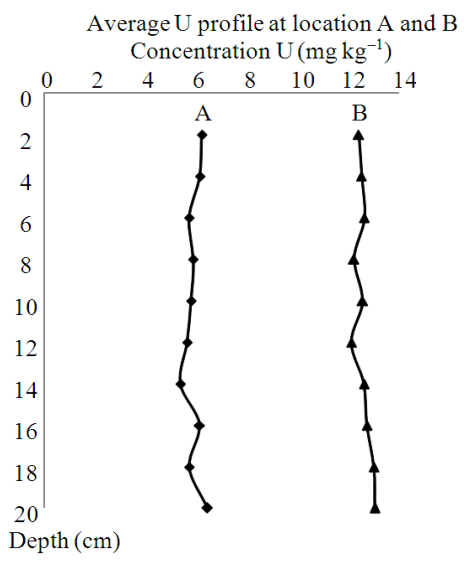

Fig. 5: Uranium profile

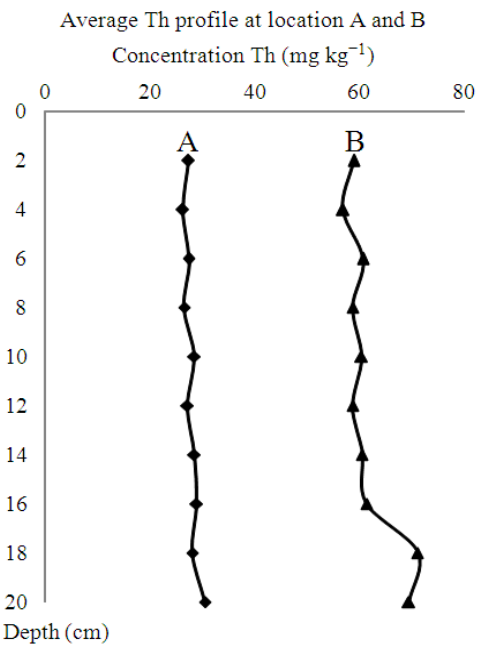

Fig. 6: Thorium profile 1309 
Am. J. Applied Sci., 8 (12): 1307-1313, 2011

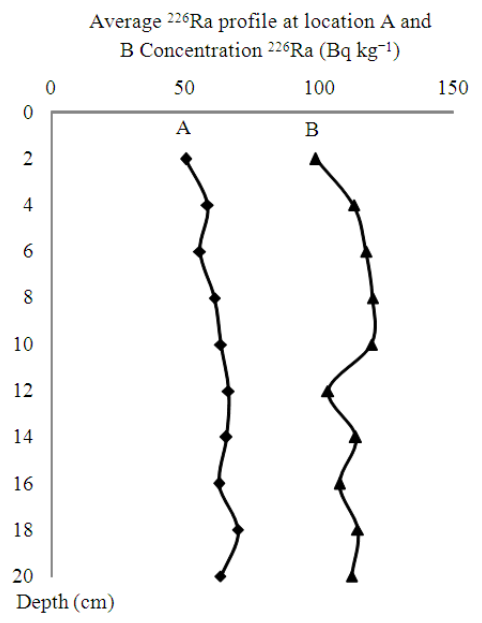

Fig. 7: ${ }^{226}$ Ra profile

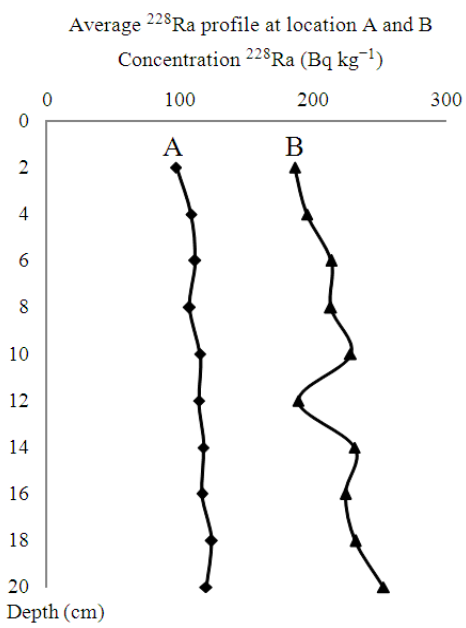

Fig. 8: ${ }^{228}$ Ra profile

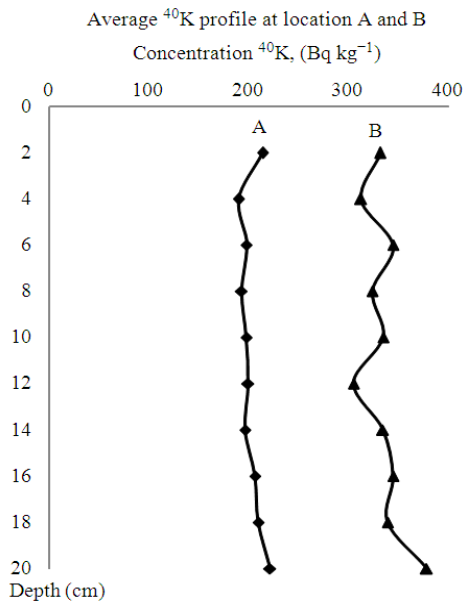

Fig. 9: ${ }^{40} \mathrm{~K}$ profile

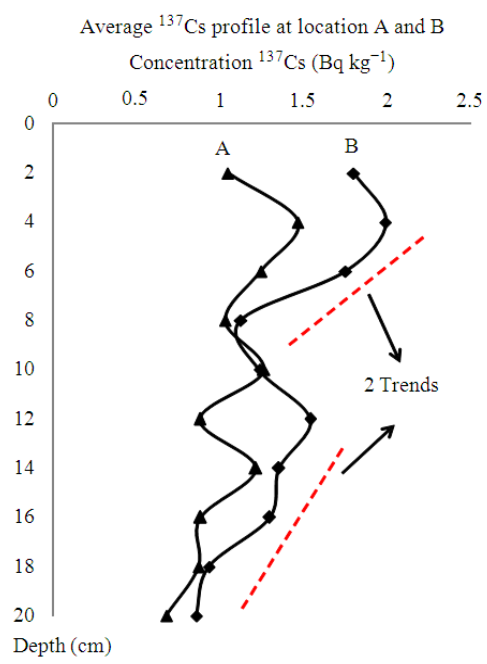

Fig. 10: ${ }^{137} \mathrm{Cs}$ profile

\section{DISCUSSION}

The concentration of $\mathrm{C}, \mathrm{N}$ and $\mathrm{P}$ are decreasing through depth while $\mathrm{K}, \mathrm{U}$ and $\mathrm{Th}$ are not changing very much with depth. The decreasing trend of these elements is due to natural process such as vertical leaching through the depth. Due to the external input from fertilizer on the top of the soil, the upper layer of the soil contains high concentration of $\mathrm{N}$ and P. For carbon, the bottom layer undergoes biodegradation and decomposition. The carbon content at the upper layer of soil is higher because of the input from decomposition of organic from leaf, root and other atmospheric deposition. The $\mathrm{K}$ show monotonic pattern through the depth, suggested that $\mathrm{K}$ is more soluble compare to the others element and the leaching process for $\mathrm{K}$ is much higher. Both plantations show different range where concentration at plantation $\mathrm{B}$ is much higher than plantation $\mathrm{A}$ for $\mathrm{C}, \mathrm{N}, \mathrm{P}$ and $\mathrm{K}$. Although the range is different, the pattern of the depth profile show no significant different.

As for ${ }^{137} \mathrm{Cs}$ where it came from anthropogenic pollution through atmospheric fallout, it can been seen that (Fig. 10) there were two trends at $2-10 \mathrm{~cm}$ and $12-$ $20 \mathrm{~cm}$ which suggested they were from nuclear weapon testing in year 1960s and Chernobyl nuclear accident 1986.

From Fig. 1-3, at layer 12 and $14 \mathrm{~cm}$, the concentration of $\mathrm{C}, \mathrm{N}$ and $\mathrm{P}$ is slightly higher than at 10 $\mathrm{cm}$ layer. The different is occurring due to the sample collection where the sample for profile was drilled twice at the same hole. Two times drilling is for layer 0$10 \mathrm{~cm}$ and $12-20 \mathrm{~cm}$ will introduce mixing layer at 12 $\mathrm{cm}$ and $14 \mathrm{~cm}$. This mixing layer contributed to the observed high concentration at 12 and $14 \mathrm{~cm}$ depth. 
Am. J. Applied Sci., 8 (12): 1307-1313, 2011

Table 2: Pearson correlation coefficient between element and isotopes at plantation A

\begin{tabular}{|c|c|c|c|c|c|c|c|c|c|c|}
\hline Variables & $\mathrm{C}$ & $\mathrm{N}$ & $\mathrm{P}$ & $\mathrm{K}$ & $\mathrm{U}$ & $\mathrm{Th}$ & ${ }^{226} \mathrm{Ra}$ & ${ }^{228} \mathrm{Ra}$ & ${ }^{40} \mathrm{~K}$ & ${ }^{137} \mathrm{Cs}$ \\
\hline $\mathrm{C}$ & 1.000 & & & & & & & & & \\
\hline $\mathrm{N}$ & 0.977 & 1.000 & & & & & & & & \\
\hline$P$ & 0.995 & 0.964 & 1.000 & & & & & & & \\
\hline K & 0.749 & 0.799 & 0.765 & 1.000 & & & & & & \\
\hline $\mathrm{U}$ & 0.108 & 0.121 & 0.156 & 0.237 & 1.000 & & & & & \\
\hline Th & -0.726 & -0.707 & -0.687 & -0.451 & 0.276 & 1.000 & & & & \\
\hline Ra-226 & -0.852 & -0.798 & -0.884 & -0.648 & -0.418 & 0.331 & 1.000 & & & \\
\hline Ra-228 & -0.915 & -0.879 & -0.916 & -0.598 & -0.275 & 0.596 & 0.879 & 1.000 & & \\
\hline K-40 & -0.369 & -0.310 & -0.310 & 0.082 & 0.554 & 0.717 & -0.015 & 0.175 & 1.000 & \\
\hline Cs-137 & 0.656 & 0.622 & 0.621 & 0.379 & -0.304 & -0.585 & -0.372 & -0.376 & -0.767 & 1 \\
\hline
\end{tabular}

Table 3: Pearson correlation coefficient between element and isotopes at plantation B

\begin{tabular}{llllllllll} 
Variables & $\mathrm{C}$ & $\mathrm{N}$ & $\mathrm{P}$ & $\mathrm{K}$ & $\mathrm{U}$ & $\mathrm{Th}$ & ${ }^{226} \mathrm{Ra}$ & ${ }^{228} \mathrm{Ra}$ & ${ }^{40} \mathrm{~K}$ \\
\hline $\mathrm{C}$ & 1 & & & & & & & & \\
$\mathrm{~N}$ & 0.986 & 1 & & & & & & \\
$\mathrm{P}$ & 0.988 & 0.976 & 1 & & & & & \\
$\mathrm{~K}$ & 0.266 & 0.258 & 0.368 & 1 & & & & \\
$\mathrm{U}$ & -0.629 & -0.659 & -0.543 & 0.468 & 1 & & & & \\
Th & -0.806 & -0.780 & -0.735 & 0.098 & 0.839 & 1 & & & \\
Ra-226 & -0.232 & -0.238 & -0.266 & -0.061 & 0.216 & 0.148 & 1 & & \\
Ra-228 & -0.809 & -0.845 & -0.796 & 0.036 & 0.785 & 0.739 & 0.524 & 1 & \\
K-40 & -0.569 & -0.573 & -0.508 & 0.433 & 0.812 & 0.709 & 0.172 & 0.807 & -0.569 \\
Cs-137 & 0.896 & 0.881 & 0.892 & 0.290 & -0.508 & -0.761 & -0.352 & -0.812 & 1 \\
\hline
\end{tabular}

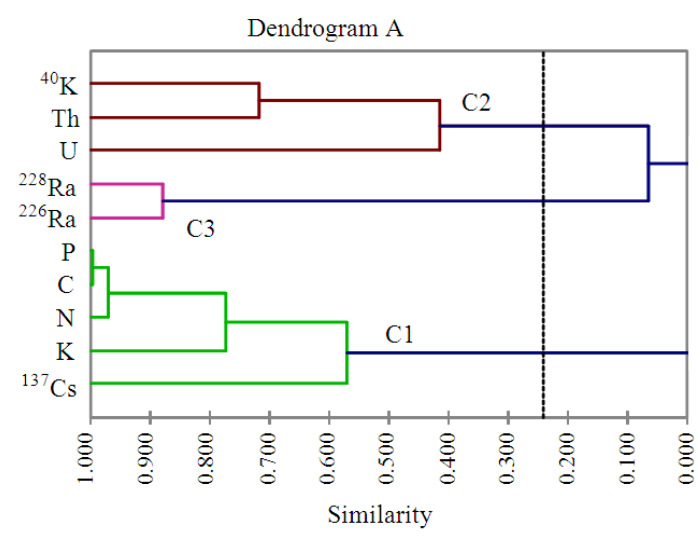

Fig. 11: Dendrogram plantation A

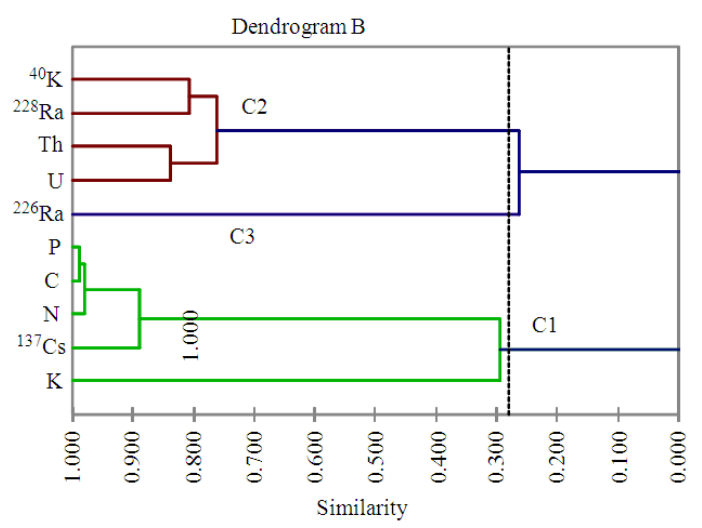

Fig. 12: Dendrogram plantation B
Pearson correlation between elements are shown in Table 2 and 3 while dendrogram for plantation A and B are shown in Fig. 11 and 12. It shows that strong correlation between $\mathrm{C}, \mathrm{N}, \mathrm{P}$ and $\mathrm{K}$ for plantation $\mathrm{A}$ and $\mathrm{B}$ except for $\mathrm{K}$ at plantation B. Dendrogram show that $\mathrm{C}, \mathrm{N}, \mathrm{P}, \mathrm{K}$ and ${ }^{137} \mathrm{Cs}$ was clustered as $\mathrm{C} 1$ group for $\mathrm{A}$ and B. U, Th, ${ }^{226} \mathrm{Ra},{ }^{228} \mathrm{Ra}$ and ${ }^{40} \mathrm{~K}$ also clustered as group $\mathrm{C} 2$ and $\mathrm{C} 3$ as we expect it is from natural origin.

Principal Component Analysis was applied to the whole set data separately for plantation A and plantation B. There are two principal components for plantation $\mathrm{A}$ and three principal components for plantation B referring eigenvalues that exceed 1 . Plantation A counted for 61.98 and $23.28 \%$ of total variation data. Plantation B counted for $64.41 \%, 18.68$ and $10.02 \%$ of total variation data respectively with a total cumulative of $85.26 \%$ and $93.11 \%$ for plantations $\mathrm{A}$ and B. For plantation A, five elements were related to factor 1 in positive direction and three elements in negative direction. $\mathrm{C}, \mathrm{N}, \mathrm{P}, \mathrm{K}$ and ${ }^{137} \mathrm{Cs}$ were related to positive factor and $\mathrm{Th},{ }^{226} \mathrm{Ra}$ and ${ }^{228} \mathrm{Ra}$ related to negative factor. $\mathrm{U}$, Th and ${ }^{40} \mathrm{~K}$ are related to factor two.

For plantation $\mathrm{B}$, factor one is related for element C, N, P and ${ }^{137} \mathrm{Cs}$. Factor two were strongly for element $\mathrm{K}, \mathrm{U}$ and ${ }^{40} \mathrm{~K} .{ }^{226} \mathrm{Ra}$ were strongly related to factor three.

Cluster Analysis (CA) for both plantation (Fig. 11 and 12), cluster $\mathrm{C} 1$ group of element consist of $\mathrm{C}, \mathrm{N}, \mathrm{P}$ and ${ }^{137} \mathrm{Cs}$ was observed for both plantation due to their trend profile that decreasing through the depth and as the elements that added to the soil. The sources of this element suggested it from fertilizer application except 1311 
for ${ }^{137} \mathrm{Cs}$ which it from anthropogenic pollution from atmospheric deposition.

$\mathrm{U}$, Th and ${ }^{40} \mathrm{~K}$ was clustered as $\mathrm{C} 2$ group for both plantations. ${ }^{226} \mathrm{Ra}$ was clustered into $\mathrm{C} 3$ group and ${ }^{228} \mathrm{Ra}$ in $\mathrm{C} 2$ group for plantation $\mathrm{B} .{ }^{226} \mathrm{Ra}$ and ${ }^{228} \mathrm{Ra}$ for plantation A was clustered in $\mathrm{C} 3$ group. $\mathrm{C} 2$ and $\mathrm{C} 3$ group was suggested come from natural occurring and atmospheric natural process. The clustering ${ }^{228} \mathrm{Ra}$ at $\mathrm{C} 3$ for Plantation $\mathrm{B}$ and $\mathrm{C} 3$ at plantation $\mathrm{A}$ maybe attributed to the different of altitude, slope, soil type and soil densities of the two study location.

As we observe the trend of $\mathrm{C}, \mathrm{N}$ and $\mathrm{P}$ is decreasing through the depth, we plot an exponential trendline to get the trend within the depth. The correlation coefficient of the exponential is in a good agreement with depth with $\mathrm{R}^{2}$ more than 0.9 by removing mixing layer.

\section{CONCLUSION}

In general the range of elemental concentration at plantation B is higher than plantation A. All depth profile give monotonically trend except for $\mathrm{C}, \mathrm{N}, \mathrm{P}$ and ${ }^{137} \mathrm{Cs}$ where elements were added to the soil which when applying fertilizer and it may originated from atmospheric process. The concentration of $\mathrm{C}, \mathrm{N}$ and $\mathrm{P}$ are decreasing exponentially with depth. ${ }^{137} \mathrm{Cs}$ was found at low activity concentration at study locations. Other radionuclide's ${ }^{226} \mathrm{Ra},{ }^{228} \mathrm{Ra}$ and ${ }^{40} \mathrm{~K}$ seem to be from natural existence and atmospheric natural process. Except for ${ }^{228} \mathrm{Ra}$, all elements are clustered in their identical respective cluster in both plantation A and B.

\section{ACKNOWLEDGEMENT}

The researchers would like to thank the Malaysia Nuclear Agency staff for their technical assistances in Elemental Analyzer measurement. Thanks to Faculty of Applied Sciences, Institute of Science and Research Management Institute (RMI), Universiti Teknologi MARA Malaysia for providing financial support and instrumentation for this research.

\section{REFERENCES}

Abdullah, M.Z., A. Saat and Z. Hamzah, 2011. Optimization of energy dispersive X-Ray fluorescence spectrometer to analyze heavy metals in moss samples. Am. J. Eng. Applied Sci. 4: 355362. DOI: $10.3844 /$ ajeassp.2011.355.362

Ademola, J.A., and A.A. Ayeni. 2010. Measurement of natural radionuclides and dose assessment of granites from Ondo State, Nigeria.
Radioprotection, 45: 513-521. DOI: 10.1051/radiopro/2010046

Alam, M.N., M.I. Chowdhury, M. Kamal, S. Ghose and H. Banu et al., 1997. Radioactivity in chemical fertilizers used in Bangladesh. Applied Radiation Isotopes, 48: 1165-1168. DOI: 10.1016/S09698043(97)00019-5

Alias, M., Z. Hamzah, A. Saat, M. Omar and A.K. Wood. 2008. An Assessment of absorbed dose and radiation hazard index from natural radioactivity. Malaysian J. Anal. Sci., 12: 195-204.

Aminuddin, B.Y., M.H. Ghulam, W.Y.W. Abdullah, M. Zulkefli and R.B. Salama, 2005. Sustainability of current agricultural practices in the Cameron Highlands, Malaysia. Water, Air Soil Poll., Focus, 51: 89-101. DOI: 10.1007/s11267-005-7405-y

Anjos, R.M., R. Veiga, T. Soares, A.M.A. Santos and J.G. Aguiar, et al., 2005. Natural radionuclide distribution in brazilian commercial granites. Radiation Measur., 39: 245-253. DOI: 10.1016/j.radmeas.2004.05.002

Carpenter, S.R., N.F. Caraco, D.L. Correll, R.W. Howarth and A.N. Sharpley et al., 1998. Nonpoint pollution of surface waters with phosphorus and nitrogen. Ecolog. Applied, 8: 559-568. DOI: 10.1890/10510761(1998)008[0559:NPOSWW]2.0.CO;2

Chandrajith, R., S. Seneviratna, K. Wickramaarachchi, T. Attanayake and T. Aturaliya et al., 2010. Natural radionuclides and trace elements in rice field soils in relation to fertilizer application: study of a chronic kidney disease area in Sri Lanka. Environ. Earth Sci., 60: 193-201. DOI: 10.1007/s12665-009-0179-1

Choudhury, A.T.M.A. and I.R. Kennedy, 2005. Nitrogen fertilizer losses from rice soils and control of environmental pollution problems. Commun. Soil Sci. Plant Anal., 36: 1625-1639. DOI: 10.1081/CSS-200059104

El-Arabi, A.M., $\quad 2007 . \quad{ }^{226} \mathrm{Ra}, \quad{ }^{232} \mathrm{Th}$ and ${ }^{40} \mathrm{~K}$ concentrations in igneous rocks from eastern desert, Egypt and its radiological implications. Radiation Measur., 42: 94-100. DOI: 10.1016/j.radmeas.2006.06.008

FAOUN, 2004. Fertilizer use by crop in Malaysia. Rome.

Favaro, D.I.T., 2005. Natural radioactivity in phosphate rock, phosphogypsum and phosphate fertilizers in Brazil. J. Radioanalyti. Nuclear Chem., 264: 445448. DOI: $10.1007 / \mathrm{s} 10967-005-0735-4$ 
Guo, Z., C. He, Y. Ma, H. Zhu and F. Liu et al., 2011. Effect of different fertilization on spring cabbage (Brassica oleracea L. var. capitata) production and fertilizer use efficiencies. Agric. Sci., 2: 208-211. DOI: 10.4236/as.2011.23029

Hamzah, Z., A. Saat, N.H. Mashuri and S.D. Redzuan, 2008. Surface radiation dose and radionuclide measurement in ex-tin mining area, $\mathrm{Kg}$ Gajah, Perak. Malaysian J. Anal. Sci., 12: 419-431.

Hamzah, Z., S.D. Riduan and A. Saat, 2011. Determination of sediment profile for ${ }^{210} \mathrm{~Pb}, \mathrm{~Pb}, \mathrm{U}$ and Th from sultan Abu Bakar dam due to soil erosion from highland agriculture area, Cameron Highlands, Malaysia. Am. J. Environ. Sci., 7: 263268. DOI: $10.3844 /$ ajessp.2011.263.268

Lettner, H., A. Griesebner, T. Peer, A.K. Hubmer and M. Pintaric, 2006. Altitude dependent ${ }^{137} \mathrm{Cs}$ concentrations in different plant species in alpine agricultural areas. J. Environ. Radioactivity, 86: 12-30. DOI: 10.1016/j.jenvrad.2005.06.007

McGee, E.J., P.A. Colgan, D.E. Dawson, B. Rafferty and C. O'Keeffe, 1992. Effects of topography on caesium-137 in montane peat soils and vegetation. Analyst, 117: 461-464. DOI: 10.1039/AN9921700461
Ministry of Agriculture and Fisheries, 1970, Generalized Soil Map Peninsular Malaysia 1970. Derectorat Pemetaan Negara, Malaysia No-1371976, 1: 800000, Kuala Lumpur.

Moura, C., A. Artur, D. Bonotto, S. Guedes and C. Martinelli, 2011. Natural radioactivity and radon exhalation rate in Brazilian igneous rocks. Applied Radiation Isotopes, 69: 1094-1099. DOI: 10.1016/j.apradiso.2011.03.004

Novotny, V., X. Wang, A. Englande, D. Bedoya and L. Promakasikorn et al., 2010. Comparative assessment of pollution by the use of industrial agricultural fertilizers in four rapidly developing Asian countries. Environ. Dev. Sustain., 12: 491509. DOI: $10.1007 / \mathrm{s} 10668-009-9207-2$

Riduan, S.D., Z. Hamzah and A. Saat, 2009. In-situ measurement of selected water quality parameters in ringlet's lake, cameron highlands. Malaysian J. Chem., 11: 122-128. 